\title{
Running head: Bail, Reform, and Foucault's Dangerous Individual
}

\author{
Wendy L. Wright, William Paterson University
}

\begin{abstract}
Over 2.5 million people in the US are incarcerated annually for the sole reason that they cannot afford cash bail. This nearly exclusively affects the working-class, and disproportionately affects Black and brown individuals and communities. Whether someone is incarcerated pending trial affects employment, family stability, and even likelihood of conviction. Across the US, reform efforts are being considered and adopted, but in this paper, I use a political theory approach to argue that racial capitalist ideologies that construct the accused as specifically 'dangerous' impede just policy transformation. I start by centralizing Michel Foucault's genealogy of the 'dangerous individual' as a frame for analyzing the logics and movement of the dangerous figure, and then resituate the concept of the dangerous person in the contemporary US bail context. Ultimately, I argue that the dominance of oppressive ideologies in the bail discourse demonstrates the pervasive race and class biases that persist in the criminal justice apparatus, even in policy reform approaches that promise unbiased outcomes like algorithmic assessments.
\end{abstract}

\section{Keywords}

Bail reform, dangerousness, Foucault, racial capitalism, neoliberal ideology

\section{Bail, Reform, and Foucault's Dangerous Individual}

Bail is almost exclusively a crisis for poor and working-class people, and is especially burdensome for urban Black and brown working-class communities. Today, about half of million people in the US are incarcerated pre-trial, while legally innocent, exclusively because they cannot afford to pay money bail. While bail reform initiatives are being considered and implemented across the United States, efforts to reform are often palled by an omnipresent image of the threatening figure. Even as empirical analyses have shown that bail reforms do not increase risks to public safety (Herring, 2020), the specter of the individual who may commit a crime, during the timeframe that they might otherwise have been incarcerated, haunts this policy discourse. This paper uses a political theory approach to explore this phenomenon through a deep engagement with Foucault's genealogy of 'the dangerous individual.' In lectures between 1974-1977, Foucault analyzed the construction of the dangerous individual as a pathologized figure forwarded by forensic psychiatry as a force in the modernizing criminal justice apparatus of the nineteenth century. In this paper, I engage Foucault's 'dangerous individual' as a means of teasing out, exploring, and theorizing today's bail reform discourse. 
Bail is a mechanism of sureties in lieu of incarceration, wherein the court requires that a thing of value, typically cash, be temporarily given to the court in order to assure that the accused will return to future court dates (the surety is forfeit if the person does not return). The average bail amount for a felony is $\$ 10,000$ in 'cash or bond.' ${ }^{1}$ Most felonies will require the non-refundable payment of a minimum of one thousand dollars to a for-profit bail bondsman, who will post bond on behalf of the accused, and take the surety as profit at the conclusion of the case. ${ }^{2}$ - Recent surveys have reported that more than two-thirds of households would be unable to readily produce that thousand dollar surety (Tolan, 2017). Bail for misdemeanors is typically much lower, though for many thousands at any given time, even smaller out-of-pocket costs are unreachable (Rockett, 2019). Many will recall the 2015 case of Sandra Bland, who was arrested in what was widely named racial harassment and was found hanged in her jail cell three days later: Bland was eligible for release the day following her arrest, but her family struggled to raise the $\$ 500$ that would have enabled them to post bond (Mansoor, 2020). The Bail Project estimates that 2.5 million people each year are incarcerated for some period of time due to unaffordable money bail (Bail Project, 2021). Not being able to post bail also has cross-cutting effects, from job loss, to family disruption, to a significant increase in the likelihood of conviction as a case outcome (Digard \& Swavola, 2019; Hunter, 2020). In addition to affecting those with lower income and wealth, working in positions without access to time-off elevates the harms of bail detention.

Across the nation, bail reform movements have been initiated, but some have foundered or even, in the case of New York, been rolled back after public outcry. Beyond the over-criminalization of working-class and poor Black and brown people as a cause of over-incarceration in the first place, the issue of bail, who can afford it, and why the bail system persists is both profoundly unequal and a vital question for those interested in race- and class-differentiated experiences of justice and freedom (Arnold et al, 2018; Peterson \& Omori, 2019; Sawyer, 2019).

In this paper, I review the current state of bail reform, and argue that persistent challenges to reform might be understood through the lens of Michel Foucault's framework of the 'dangerous individual,' a concept that emerges within the context of larger issues of biopolitics. After arguing for the relevance of the dangerous individual framework, I discuss the deep-seated ideological dominance of the dangerous individual, and argue that has profound effects on the possibilities for justice in the pre-trial criminal justice system, with particularly devastating effects on poor and working-class communities of color, who may be prefigured as particularly dangerous in ways that intensify the effects of bail inequalities.

\footnotetext{
${ }^{1}$ A felony is the most common, though not universal, category in the United States of relatively serious offenses, typically distinguished from 'misdemeanors.' While there is variation across state jurisdictions, a felony is generally any criminal offense for which the maximum sentence is one year or more in prison. An example of this distinction is that under Illinois law, theft of property worth less than $\$ 500$ is a misdemeanor, but theft of property worth more than $\$ 500$ is a felony.

${ }^{2}$ While a number of countries use cash bail in some ways, the United States and the Phillipines are considered outliers wherein a significant industry has developed around providing sureties. See Shima Baradaran Baughmna's book The Bail Book (2017) for further detail.
} 


\section{The State of Bail}

The money bail system that has dominated most US state criminal justice systems in the modern era is widely seen as problematic, self-evidently producing class-differentiated inequality. In response, bail reform is one of the most widespread, transformative movements happening in the US criminal justice field, even as it is one of the quietest (Starger \& Bullock, 2018). While bail reform sometimes received less attention than other decarceration movements, bail reform has the possibility to utterly transform the average arrestee's experience of the US criminal justice system (Cohen \& Reaves, 2007; Gupta et al., 2016; Rengifo et al, 2021). Nation-wide, there are organizations working to reform the system that keeps hundreds of thousands of poor people behind bars, exclusively for want of a few hundred or thousand dollars. Some states, like New Jersey, have recently implemented radical bail reform through the legislative process (Rengifo et al, 2021). Other states, like California, have rejected wholesale reform, but are seeing challenges through legal advocacy and activism (Coffman, 2018). According to the Pretrial Justice Initiative, in only 11 states has there been no recent major activity toward 'improving' pretrial processes (Pretrial Justice Institute, 2021). Much of the dominant discourse has identified money bail as the problem, and a shift to a non-money, risk-based assessment as the obvious, progressive solution. However, in this paper, I explore deeper ideological factors that elude the simple, seemingly valuefree solution of quantitative risk assessment. This article contributes to the emerging literature that is more deeply suspicious of algorithmic justice, which seeks to use complex scoring tools to identify riskiness in the accused (Eckhouse et al, 2019; Green, 2020; McKay, 2020; van Eijk, 2020.), but also contributes to a less developed literature that forwards a theoretical analysis of the role of ideology, identity, and power in bail.

Bail reform, as debated or adopted, has garnered a complicated response. In NJ, jail populations fell by about $20 \%$ across the board in the year following reform implementation. This has clearly been a boon for the several thousand individuals who would otherwise be incarcerated, but it has transformed the for-profit bail bond industry, shuttering many small businesses (Conte, 2020). Further, while on the whole, bail reform does not appear to harm public safety, there have been several reports of violent crimes being committed by individuals free from jail, who under the previous system would likely have still been incarcerated (Schuppe, 2020). Less discussed, but more troubling for proponents of progressive reform, is that there are strong indications that bail reform may be exacerbating racial disparities, largely through the use of ostensibly race-neutral, but in actuality deeply racialized risk-assessment tools (Eckhouse et al, 2019; Green 2020). Thus, it is white defendants who have thus far benefited most from bail reform.

Risk-assessment tools have a long and inarguably biased history. The first generation of instruments was developed largely based on a 'common-sense' approach that relied on items like length of time at address, which quickly were seen to be more measures of economic and/or racial status than of public safety or likely failure-to-return risk (Koepke \& Robinson, 2018; Werth, 2019). That new bail assessment instruments may be imbued with pre-existing biases, especially racial and class biases, is not a novel claim. Opponents of an uncritical big-data approach to criminal justice assessments have hailed from political, legal, and scholarly fields. In 2014, thenAttorney General Eric Holder warned that risk assessments (be they used in bail, sentencing, or other venues) 'may exacerbate unwarranted and unjust disparities that are already far too common in our criminal justice system and in our society' (Holder, 2014). Risk, the use of algorithms to 
claim bias-free analysis, and the incorporated oppressive ideology in penal settings including sentencing and parole has been explored by scholars including Kelly Hannah-Moffat, Kelly Montford, and Robert Werth (Hannah-Moffat and Struthers Montford, 2019; Werth, 2018, 2019). However, bail practices—where by definition, no one's guilt has been determined—remain sites of actuarial dominance.

Pretrial reform advocates have argued that well-designed bail assessments can be race-neutral, even as they do not solve pre-existing inequalities (Pretrial Justice Institute, 2017). Further, it is argued, by releasing a significant percentage of those who would otherwise be detained, people of color (who are arrested at higher rates) will benefit. However, reform advocates base their assessments on the likelihood of detention based on specific scoring on specific assessments. Their findings emphasize that individuals with similar scores will be released or detained at similar rates. But the problem of a snowballing effect of racial inequality in policing, legal representation, and sentencing is left unaddressed. ${ }^{3}$

Across states who have begun to implement reforms, there are formal reports and news stories focusing on defendants who committed new, often violent, crimes while pending trial, whereas under previous pretrial models they might have been incarcerated at the time of the instant offense. These crimes, even as they do not statistically increase crime rates, and constitute a small percentage of the overall released population, test the political will of both reformers and the public at-large (Herring, 2020).

Even as the first waves of pre-/post-bail reform (often referred to as 'system improvement' within the pretrial community) have shown no blanket increase in new arrest rates, the concern with the dangerousness of the released defendant, who otherwise would be confined, persists, beyond data or even ethical analysis (Koepke \& Robinson, 2018; Mayson, 2017). Once arrested, the arrestee, no matter the legal status of innocent until proven guilty, has been marked out as potentially dangerous, but also potentially controlled.

There is a constant refrain in the discourse surrounding bail reform focusing on the potential danger of he-who-is-released. ${ }^{4}$ Law and order politicians hold up this example, real or imagined, as a requirement for an authoritative approach. Bail bondsmen proffer this 'dark' figure ahead of the profit motive. ${ }^{5}$ No matter that empirically, there is no evidence to show that these individuals represent any particular striking threat - or a threat that would not have been able to post release bond in traditional systems - the danger the now-released person poses is a central figure in bail reform discourse. The ideological construction of the maybe-released person rests on deep ideological constructions of Blackness and unspecified lower-class-ness. Emily Brissette has argued that arraignments (the hearings at which initial bail determinations are made) are 'ritualized

\footnotetext{
${ }^{3}$ While many still hold this view, the Pretrial Justice Initiative, a leading think tank reversed their position on algorithmic risk assessment tools in 2020 following a great deal of pushback on their position that 'race-neutral' assessments were sufficiently beneficial.

${ }^{4}$ This figure is proffered as a shadow figure, but is consistently race, classed, and gendered, and is meant to provoke fear in the middle- and upper-class imagination as an Other who can only be understood as a thread. Here I use 'he' as an indication of the gendered, even as unidentified, figure associated with crime.

${ }^{5}$ Many bail bonds professionals forward images of potentially unsecured offenders with highly racialized subtext. In commenting on New York's bail reform, one bail bond professional held up the 'drug dealers' and 'gangs' (coded Black and brown) with 'soccer moms, ... the tourists' (coded white) (Rayman, 2019).
} 
practices' which together represent and interpellate the accused as a 'bad subject' (Brissette, 2020). The arrestee's life as a parent, a worker or community member is rendered invisible and irrelevant by the dominance of the imagined threat.

\section{The Construction and Persistence of Foucault's Dangerous Individual}

A deep read into Foucault's exploration of the figure of the dangerous individual offers much to help in interpreting the persistence of the specter of the potentially-released defendant. By mapping the disciplinary emergence of psychiatry as a socially, politically, and legally powerful body, Foucault frames this within broader anxieties about rationality in the emergence of the modern society. In this section, I trace Foucault's argument identifying the dangerous person and its centrality in the modern state framework.

Foucault, in a 1977 lecture (turned article), 'About the Concept of the 'Dangerous Individual' in $19^{\text {th }}$ Century Legal Psychiatry' and later an interview, 'Danger, Crime and Rights: A Conversation between Michel Foucault and Jonathan Simon,' explored the origins of the specified dangerous figure in the criminal justice apparatus, as well as how and in what ways this figure has persisted and changed into the contemporary moment. These brief texts should be understood within the larger contexts of the work collected in Abnormal: Lectures at the College de France 1974-1975, Society Must be Defended: Lectures at the College de France 1975-76 and Security, Territory, Population, Lectures at the College de France, 1977-78, and of course Discipline and Punish.

Discipline and Punish: Birth of a Prison plays a large, mostly implicit role in this argument, as the penal framework here is a sizeable shorthand for the larger argument about punishment seeking to transform the individual soul within the mass institution of the prison. This is all part of the larger argument Foucault is making in the mid-1970s about the functioning of power in the modern technical state, but in focusing in on the particular processes of the construction of the dangerous individual and its relationship to the contemporary bail context, there is an opportunity for a particularly clear view of both Foucault's thinking and the operation of ideology in political institutions.

Out of the larger context of Foucault's work, I think most importantly, is the explication of the concept of biopower as a setting for the more specific exploration of dangerousness. Biopower, or 'power's hold over life,' refers to the exertion of state control over the biological. This is articulated as a different, new form of sovereignty that emerges in the nineteenth century. Previously, the right of the sovereign should be properly understood as a right to 'take life or let live' (Foucault, 2003, p. 241). Biopower as a new exercise of sovereignty, is constituted by 'the right to make live and to let die.' Foucault was primarily an analyst of power, and thought that the study of power ought to begin at the point 'where it is exercised over individuals rather than legitimated at the centre' (Jessop, 2017, p. 5), and so a microanalysis that focuses on the individualized body as the point where power meets flesh, as in bail, is particularly relevant.

Through biopower, which begins to emerge in the second-half of the eighteenth century and is fully developed in the nineteenth, shifts from the discipline of 'man' as individual, to the rule of man as the collected 'global mass' of those whose lives are affected by the (inevitable) elements 
of the biological (Foucault, 2003, p. 271). ${ }^{6}$ As Nikolas Rose describes the biopolitical turn, 'Political authorities, in alliance with many others, have taken on the task of the management of life in the name of the well-being of the population as a vital order and of each of its living subjects' (Rose, 2001, p. 1). Biopolitics seeks to control in the first order, the processes of biological life, such as 'birth rate, mortality rate, longevity,' but also beyond the basics of biological life, 'a whole series of related economic and political problems' (Foucault, 2003, p. 243). An element of this is the emergence of the field of public hygiene, which develops both institutions and knowledges of various functions of the monitored body. This paper argues that contemporary bail discourse operates through a frame that is analogically and genealogically continuous with this public hygiene frame.

This point of public hygiene is the arena through which Foucault details the medicalization of the criminal justice sphere, via legal psychiatry. In the lecture 'About the Concept of the 'Dangerous Individual in $19^{\text {th }}$ Century Legal Psychiatry,' Foucault explores the 'mechanisms, techniques, and technologies of power' $(2003$, p. 241) that characterize the emergence of public hygiene and its role in the criminal justice system. This lecture was a distillation of many of the themes that had been previously developed in Foucault's 1974-75 lectures at the College de France, and which were published in English as Abnormal.

Foucault argues that the 'psychiatrization of criminal danger' occurs in two stages in the nineteenth and twentieth centuries. The first stage, which he points to via a series of cases between 1800 and 1835 , focuses on the unreasonable crime. These are offenses committed by people who would otherwise appear to be rational and healthy individuals. Prior to this, mental status was recognized only in cases of 'dementia' or 'furor,' where in both, 'the insanity manifested itself through numerous signs which were easy enough to recognize' (Foucault, 1978, p.4). In these new cases, there was no prior indication of madness, nor other than the instance of the crime itself, was there any further sign of infirmity. Also different was that the offenses identified were particularly horrific - almost exclusively murders with no cause either before or after the offense; prior crimes of mental status had tended to be petty violence or public disorder. Foucault identifies this as a series of cases which might be understood as crimes against nature, rather than offenses merely against society.

Finally and most importantly, these are crimes with no reason. In the $18^{\text {th }}$ century, a discourse around crime as violations of reason became the narrative of law and law-breaking, but with this turn, came the events that undermine this narrative. The law, grounded in reason, could not immediately respond within its own boundaries. As the law, as embodied in the judiciary, but also in the larger juridical framework of lawyers, jails, and the emerging prisons, the centrality of the figure of the rational actor choosing to law-break required a reasonable narrative of a crime in order to make it 'intelligible.' Foucault outlines this via example. First, he notes that under the

\footnotetext{
${ }^{6}$ I think something implicit in Foucault's argument here is the fundamental economism of human life. The fact of our existence as necessitous beings - creatures that need food-water-shelter-society - is the central element of Marx's analysis of the functions of capitalism in the nineteenth century, and this is one area of Foucault's 'uninterrupted dialogue' with Marx (Fontana \& Bertani, 2003 p. 277). Foucault's articulation of biopower acknowledges the complexity of organized life outside of a subsistence model. As economic society complicates, especially under the industrial model, control over necessity might be understood to be wrested from nature, but is vested in capital as an accumulation of labor-time. Moving from this macro understanding, Foucault drills down to the mechanisms that proceed from this organization of need.
} 
French system he is examining, if the accused is found to be irrational, then the crime itself is negated (this is different from the US system wherein the crime remains, but the criminal is judged to be not-responsible; this is a legal difference). It is only through an articulable motivation that the crime is circumscribed in the legal order. He gives the example of a story in which a poor woman kills a child and eats her. This woman is condemned, but Foucault counters that had the woman been rich, this crime would have been seen as an act of madness, rather than sheer criminality. Their actions cannot be explained through reason and the juridical order cannot account for such.

At the same time as the courts were finding their current schema inadequate to respond to this certain class of crimes, the newly emergent profession of psychiatry was establishing itself as a legitimate branch of medicine - and found this crime-out-of-context explainable by naming it madness. Foucault identifies this as an active process by psychiatrists trying 'very stubbornly to take their place in the legal machinery' (Foucault, 1978, p. 6). This stubbornness is described as taking place because the legal order functioned as a modality of power to be secured and justified. And this is possible because here psychiatry is acting to disseminate a framework of public hygiene, which-as discussed above-develops both institutions and knowledges of various functions of the monitored body. Here the monitored body is the body of the unusual, horrific criminal.

Foucault argues that it was via its operation in the legal sphere that psychiatry was able to establish itself so well. These crimes could not be accounted for in the traditional juridical order, but the intervention of the psychiatrist saves the legal framework as a comprehensive body by finding a rational explanation for how these individuals must be situated and managed. Only technicians of public hygiene are able to make effective judgments about the irrational actors who are acting in criminal ways. This particular kind of insanity especially required an experienced and trained eye, because homicidal monomania 'remained invisible until it explode[d].' Foucault notes that it is both audacious and necessary that this intervention must come through such an 'extravagant' a crime as homicidal mania, a crime that had 'a maximum of consequences, a minimum of warning' (1978, p. 7) in part because such violations required response, but did not fit a rational narrativeso they must be mad - and are thus ineligible for management through the extant criminal justice system.

Foucault explores how psychiatry as part of its establishing authority as a discipline, became authoritative, even as judges and prosecutors objected. Foucault argues that as legal psychiatry expanded its institutional power, the importance of maintaining public hygiene created the demand for the psychiatrist as solution. Convicted criminals were punished in order to correct the failing that resulted in crimes being committed, but without a possibility of correction, a prime contemporary function of punishment is left rudderless. Punishment had adopted the power to transform the soul, but when a crime is so out of character there may be nothing to transformthus the criminal must be consigned not to the prison, but to the care of the psychiatrist via the institution. Even when jurists resisted the encroachment of psychiatry, they were ultimately required to accept the incursions even if only at the most extreme bounds of criminality. This is a circular logic, that when unraveled can be seem to be built on fog. In the earlier lectures, Foucault characterized the psychiatric position as speaking 'the language of children and the language of fear' (Foucault, 2003a, p. 36): the person is dangerous because the psychiatric authority says so- 
so there. Contemporary discourse around bail functions along a similar mirage: non-dangerous people should of course be released, but they are all actually dangerous.

Foucault argues this early nineteenth century moment set the grounds for legal psychiatry to be engaged in the identification and management of a certain type of dangerous individual - that individual whose danger cannot be predicted or managed. Thus begins the process of understanding the offender as one who must be held suspect, whose potential viciousness requires the application of expert techniques. And through the century, we begin to see the discourse of a relationship between criminality, dangerousness, and insanity slipping into, seeping across, and soaking through the juridical order. A central mechanism for this is the massification of an understanding of social ills as a function of 'degeneration.' Degeneration is a concept that emerges in several of Foucault's texts, ${ }^{7}$ the most important implication of which, for this paper, is the idea that even the smallest infraction might be an indication of future danger to come (remember, legal psychiatry enters the field to engage with crimes of which there was no warning - the shift to a model of degeneration suggests that small violations, petty crime, a. are the harbingers, but more importantly, b. are a sign of degeneration within the social body - the flaking skin to be confronted in order to maintain public hygiene). The notion of degeneration made it possible to link the most insignificant of criminals to a peril of pathological dimensions for society, and, eventually, for the whole human species. The whole field of infractions could be held together in terms of danger and thus of protection to be provided. Further, in the face of degeneration, the existing juridical framework was unable to account for this social concept within its own norms - and in Foucault's telling, the whole of the legal order largely adopts this conception, leaving the impulse to manage degeneration through a psychiatric model to exist as an overlay to the entirety of the criminal system. Foucault argues that this is so, even when the norms and propositions by those pushing the degeneration model are ostensibly rebuffed in dominant discourse. This essentially confronts the rule of law, creating a mirror system where danger becomes the metric of judgment rather than justice. We see similar patterns occurring in the turn toward algorithmic assessments in bail adjudication, even as assessments have been found to consistently, as the Pretrial Justice Institute argues, 'derived from data reflecting structural racism and institutional inequity that impact our court and law enforcement policies and practices' (PJI Team, 2020). That is, the degenerative model comes to paint individuals from criminalized communities as dangerous criminals, no matter the specific realities of their arrest.

Identifying another key period in the development of the relationship between psychiatry and criminal law, Foucault points to the second half of the nineteenth century as crucial as psychiatry contorts and expands to respond to new social demands, especially the management of the social problem of crime, which, Foucault notes that 'for all sorts of reasons, [...] there was a very strong social and political demand for a reaction to, and for repression of crime' (Foucault, 1978, p. 13). One of the paths of response to this is the emergence, by the start of the twentieth century, of 'risk' via a liability model, as the dominant ideological framework in play for criminal judgment. This effective result of this is a shift that focuses on the displacement of the danger from the crime to the criminal. Under this new regime, 'the crime tends to be no more than the event which signals the existence of a dangerous element' (Foucault, 1978, p. 2). Under this schema, the dangerous

\footnotetext{
${ }^{7}$ For more context on degeneration, see Foucault's larger argument on the nature of police regulation and governmentality, especially in Foucault, M. (2007). Security, territory, population: lectures at the Collège de France, 1977-78. Springer.
} 
person is signified by the accusation. Bail reform is then refigured as always already a discussion about minimizing absolute risk, where absolute risk is undefinable.

\section{Framing Bail Reform}

And this is where we return to the question of bail, bail reform, and how one might interpret emerging movements toward bail reform and the mechanisms by which bail is being reformed. While there are a diversity of policy positions, even on the 'progressive' side of the policy argument, the specter of the dangerous individual looms. For those opposing bail reform (at least as 'reform' is currently understood to mean detaining fewer pretrial arrestees), arguments tend to fall into one of two thematic groups: one group driven by a law \& order ideology and the bail bond industry.

The law \& order discourse hews most closely to the 'dangerous person' discourse, emphasizing the risk of release. Foucault's description of the visage of degeneracy, combined with long practice in the stigmatization of the petty criminal, results in a policy position that resists any attempt to liberalize release standards. This of course, runs afoul of the presumption of innocence, but holds strong sway. The only way to prevent the possibility of further risk to the non-incarcerated community is to defensively detain. Those arrested of violent crime are seen as obviously risky, and current bail reforms typically strengthen the court's ability to detain those accused of violent crimes. However, the vast majority of those arrested - the non-violent, low-level arrestee, also take on the mantle of the unruly risk. Past accused unruliness-violent or not, it all falls under this framework of the unreliable, potentially irrational, dangerous person-creates an absolute category of risky: the individual who is constructed as always already potentially harmful. The potential risk in release becomes the controlling metric when assessing 'the dangerous person.'

This imagining becomes possible because there is no real metric of sufficiently not-dangerous. This modern strategy of forwarding risk 'denotes a family of ways of thinking and acting, involving calculations about probable futures in the present followed by interventions into the present in order to control that potential future' (Rose, 2001, p 7) -it's always the same 'childish,' 'fearful' frame that asserts its validity on a foundation of imagined terror. The nature of human existence is risky, and while empirically, it is possible and reasonable to balance and compare risks, in the discourse of the dangerous person, the dangerousness outweighs all other actuarial accounts. Under this model, it does not matter even if research finds that bail reform might prevent the release of other, more likely-to-be-dangerous arrestees, ${ }^{8}$ the release of any particular unruly body presents a violation of the sanctity of the commons to be free from such unruliness whenever and wherever possible. The risk of the dangerous person as fetishized in the body of he-whowould-be-released becomes an absolute metric.

\footnotetext{
${ }^{8}$ Under a true money bail system, higher risk detainees retain the option to secure release through a money bond. That bond will be much higher than the bond required for low level offenders, but is still an option. For serious criminals, the proceeds of criminal activity sometimes actually make higher-level money bond more accessible than a lower bond might be to a petty offender. Under most reform models, 'high-risk' arrestees are precluded from release at all. In NJ, part of the political horse-trading to reach a deal on bail reform including precluding many classes of offenses characterized as dangerous from bail eligibility at all.
} 
The second powerful vector in the anti-reform camp is the basic market interest of the bail bond industry. The bail industry, which is primarily composed of small, often family, businesses, profits by taking a fee and contracting collateral from the defendant and posting the remainder surety on behalf of the defendant. For example, if a person is required to post a $\$ 5,000$ bail, a person's family might pay a bail bond agency $\$ 500$, and the bail company would post the remainder (or a promissory bond). If the arrestee does not return to court, the bail is forfeit. Thus the bail industry serves a role in ensuring those released return to court. When a person does not appear as required, bail bond agencies will often perform their own arrests, forcibly returning the arrestee to court.

The bail industry has been a powerful lobbying voice against bail reform at the ballot box and in legislative debates. Two main arguments are offered. The first argument is that bail bondsmen perform a valuable service in ensuring arrestees' return to court. However, there is little evidence to support this claim. In the recent pre- and post-reform implementation analyses, there is no significant difference between the court appearance rates of bailed v. released arrestees (Brooker, 2017). Second, that bail reform will be devastating to this small business sector. This argument, when considered in relationship to the construction of the arrestee as a categorical dangerous person reveals a certain orientation toward the value and integrity of the accused. The implicit principle is that the economic well-being ought to trump any and all benefits that might accrue to a person who is released rather than incarcerated. Here, the degenerated value of the dangerous person-one whose multifarious wellbeing, but also crucially his literal freedom, is subjugated to the bail bondsmen. The power of a dominating narrative assigning the arrested to such a status becomes evident in this comparison.

On the opposite, pro-reform side, while the dangerous individual narrative does not dominate, it remains a subtext - but one that is argued to be managed through alternative state technologies. Bail reform advocates argue that they are advocating for a less punitive, more just approach, one that is more respectful of the presumption of innocence, very few argue for a switch to a system premised on release on recognizance. This is the presence of the dangerous individual, that childish and fearful language dominating, even as the courts articulate themselves through the scientization of the algorithm. Instead, under most bail reform models across the US, while most arrestees would be bailed, the vast majority would be released under various sets of surveillance conditions, such as house arrest, GPS monitoring, or required reporting. NJ, the bastion of progressive bail reform has thirteen such requirements. Failure to comply with these requirements can result in bail revocation. While these measures are posited as softer, kinder, gentler, more just interventions, the long history of use of these mechanisms for parole and probation suggests otherwise. Criminologist James Kilgore argues that 'the majority of EM [electronic monitoring] regimes are fully in line with the paradigm of punishment that has dominated the criminal justice system for more than three decades' (Kilgore, 2013). Individuals who have been monitored have reported that in-community monitoring is aggressively disruptive, and interferes with employment, family responsibilities, and psychological well-being - theoretically the exact harms bail reform advocates say they wish to mitigate. Parolee David Dupree described GPS monitoring as making him feel like a 'dog that's on an invisible fence' (Rickert, 2018). Here, the accused is still posited as the dangerous individual, but one whose posed risk can be managed effectively through emergent state technologies. ${ }^{9}$

\footnotetext{
${ }^{9}$ It is also important to note that the shift toward expanding state surveillance is not benign. There is further danger
} in expanding the use of state surveillance, as individuals who would previously have been eligible for release under 


\section{Bail, the Dangerous Individual, and Racial Capitalist Ideology}

Deploying Foucault's dangerous individual is not a historic argument, but rather is an attempt to bring a relevant category into view as a methodological fragment. However, it is also important to re-historicize and re-locate bail discourses within the US's specific bail history. As Dabney et al (2017) argue, bail practices in the US enclose the logics of earlier eras of penal ideology while also being 'tinted' with emergent neoliberal and neoconservative impulses over the past fifty years. Daubner et al also emphasize that the increased emphasis on dangerousness is a characteristic of neoconservative influence that emerges as part of broader sociopolitical turns toward law and order politics. Also central to the emergence of neoconservative law and order-ism of the 1970s and 1980 s is the reconfiguring of the criminal justice system as the new central mechanism is maintaining the US racial order (Alexander, 2012).

Dangerousness in this context is inseparable from broader white supremacist politics in the postCivil Rights Movement era. As Khalil Muhammed has argued, blackness in the United States has always been stigmatized with connotations of criminality, that white supremacy has mobilized criminalization as a tool in the production of racist ideology (Muhammed, 2011). Previously, I've argued that race and class intersect in the neoliberal city to mark non-wealthy people of color as always already identified as unruly, dangerous, and in need of state management (Wright 2016). The process through legal psychiatry that Foucault describes was not the origin of the construction of the subjugated classes as dangerous - that required hundreds of years of aggressive, violent white supremacy explicitly enforced through social, economic, legal, and political forms - but it does demonstrate the sanitization and legitimation of this discourse into modern juridical forms. This is an example of what Murakawa and Beckett call 'racial innocence' (Murakawa \& Beckett, 2010), the process through which white supremacist action retains legitimacy by appearing raceneutral, but functions through embedded, silent forms of racial disparity.

Alongside, intertwined with racial formation is the neoliberal ideology that constructs workingclass bodies as valuable to the extent that they service capital, and defines them as criminal and dangerous to the extent when seen as disrupting the expansion of capital interests (Wright, 2016). White working-class individuals and communities are often assimilated into the management and maintenance of the criminal justice apparatus (Gilmore, 2007), through accessing social and economic mobility through employment in policing and corrections agencies-while BIPOC individuals have joined these institutions in recent years, criminal justice remains dominated by white bodies and ideologies (Whitehead, 2015). Black and brown working-class people are the fodder for these systems; lack of access to pretrial release is a process of extraction of value as they are reduced to bodies whose economic role is to be disciplined and controlled - all enabled and legitimated by the persistent forwarding of the dangerousness trope. Until this inherent

the most minimal of conditions, provided they had the cash, are now released under an aggressively expanded state surveillance apparatus. This seems poised to normalize mundane monitoring of the 'dangerous classes,' further opening what might have been otherwise protected as a matter of due process rights. This ongoing, encroaching march of state power, even as steel bars give way to signal bars, expands the reach of the security state in ever more subtle, inextricable ways. One might think of the data collected through GPS monitoring - to whom does it belong? How can it be used? Will that data be recollected in a recursive process of further refinement of algorithm-driven governing? What happens next? That these are decisions made by power elites that will determine the futures of those who are almost entirely separated from those mechanisms of power suggests the ability to resist the ideological formation of the dangerous individual may be limited. 
ideology is confronted, reforms will continue to reproduce extant forms of injustice, no matter how sophisticated the algorithm or assessment.

\section{Conclusion}

Bail policies are, like so many other areas of public policy, designed, but rarely experienced by the elite. Perhaps most like abortion access, bail will never be a problem for the economically privileged classes, but has pressing, life-altering effects for those with economic restrictions. In addition, beyond the impact on individuals, bail practices change the social, familial, and economic realities for many urban, Black and brown, working-class communities - to the extent that understanding the dynamics of bail is crucial to understanding the ways that many racialized working-class individuals and communities experience the world.

Viewing jail and bail through the lens of the dangerous individual makes apparent the chasm between legitimate democratic ends for a criminal justice apparatus and current bail policies. Decisions about incarcerating individuals, driven prior to arrest by racist, classist practices in policing, exacerbated by racist, classist practices around detention and the judicial process, continued through further racism and classism in penal practices, are made through ideological lenses that are incapable of recognizing the humanity of the working-class. Under this ideological regime, jails must be interpreted as tools of oppression, not safety, and resisted as such.

\section{Acknowledgements}

I'd like to thank Kevin Henderson, and anonymous reviewers for their feedback on this work. I'd also like to thank Brittany Gammett for embracing bail as a subject, and Ashley Glassburn, Audrey Devine-Eller, Colby King and JJ Koczan for their support of this project.

\section{Author Bio}

Wendy Wright is an Assistant Professor in the Department of Political Science, Legal, and Urban Studies at William Paterson University. She teaches courses in Legal Studies, Women's \& Gender Studies, and in the graduate program in Public Policy. Her research focuses on using critical theory to interpret and critique contemporary law and policy, especially in relation to criminal justice institutions. She has published articles in Social Justice, New Political Science, Public Integrity, and chapters in several books. Her book manuscript, The Failure of Punishment in the US Racial State is currently under contract with Routledge and is expected to be published in late 2022.

\section{Bibliography}

Alexander, M. (2012). The New Jim Crow. The New Press.

Arnold, D., Dobbie, W., \& Yang, C. S. (2018). Racial Bias in Bail Decisions. Quarterly Journal of Economics, 133(4), 1885-1932. https://doi.org/10.1093/qje/qiy012

Baughman, S.B. The Bail Book: A Comprehensive Look at Bail in America's Criminal Justice System. Cambridge University Press, 2017. 
Baughman, S. B. (2019). Dividing Bail Reform. Iowa Law Review, 105, 947.

Brissette, E. (2020). Bad Subjects: Epistemic violence at arraignment. Theoretical Criminology, 24(2), 353-369. https://doi.org/10.1177/1362480618799743

Brooker, C. (2017). Yakima County, Washington Pretrial Justice System Improvements: Claire M. B. Brooker November 2017 A Product of the Smart Pretrial Demonstration Initiative Preand Post- Implementation Analysis (Smart Pretrial Demonstration Initiative). Pretrial Justice Initiative. https://university.pretrial.org/HigherLogic/System/DownloadDocumentFile.ashx?Docum entFileKey $=$ cd5b7e4e-cc63-dffd-1419-633fed1b64bf\&forceDialog=0

Buskey, B. (2019). Wrestling with Risk: The Questions beyond Money Bail. North Carolina Law Review, 98, 379.

Cheliotis, L. K. (2006). How iron is the iron cage of new penology?: The role of human agency in the implementation of criminal justice policy. Punishment \& Society, 8(3), 313-340. https://doi.org/10.1177/1462474506064700

Coffman, J. (2018). Why Do Bail Abolition Advocates Oppose the California Money Bail Reform Act? SLU Law Journal Online, 27. https://scholarship.law.slu.edu/lawjournalonline/27

Cohen, T., \& Reaves, B. (2007). Pretrial Release of Felony Defendants in State Courts | Office of Justice Programs. https://www.ojp.gov/ncjrs/virtual-library/abstracts/pretrial-releasefelony-defendants-state-courts

Conte, M. (2017, January 17). Bail reform is killing our business, bail bondsmen say-Nj.com. https://www.nj.com/hudson/2017/01/nj_bail_reform_leaves_bail_bondsmen_in_a_tight_s po.html

Dabney, D., Page, J., \& Topalli, V. (2017). American Bail and the Tinting of Criminal Justice The Howard Journal of Crime and Justice. 56(4), pp. 397-418. https://doi.org/10.1111/hojo.12212

Digard, L., \& Swavola, E. (2019, April). Justice Denied: The Harmful and Lasting Effects of Pretrial Detention. Vera Institute of Justice. https://www.vera.org/publications/for-the-r ecord-justice-denied-pretrial-detention

Eckhouse, L., Lum, K., Conti-Cook, C., \& Ciccolini, J. (2019). Layers of Bias: A Unified Approach for Understanding Problems With Risk Assessment. Criminal Justice and Behavior, 46(2), 185-209. https://doi.org/10.1177/0093854818811379

Eijk, G. van. (2020). Algorithmic reasoning: The production of subjectivity through data. In The Algorithmic Society. Routledge.

Fontana, A., \& Bertani, M. (2003). Situating the Lectures. In D. Macey (Trans.), Society Must Be Defended: Lectures at the College de France 1975-76. Macmillan.

Foucault, M. (2007). Security, Territory, Population: Lectures at the College De France, 1977 78. Springer.

Foucault, M., Baudot, A., \& Couchman, J. (1978). About the concept of the 'dangerous individual' in 19th-century legal psychiatry. International Journal of Law and Psychiatry, 1(1), 1-18. https://doi.org/10.1016/0160-2527(78)90020-1

Foucault, M. \& Ewald, F. (2003a). Abnormal: Lectures at the Collège de France, 1974-1975. Verso.

Foucault, M., \& Ewald, F. (2003b). 'Society Must Be Defended': Lectures at the Collège de France, 1975-1976. Macmillan.

Foucault, M., Simon, J., \& Elden, S. (2017). Danger, Crime and Rights: A Conversation between Michel Foucault and Jonathan Simon. Theory, Culture \& Society, 34(1), 3-27. 
https://doi.org/10.1177/0263276416640070

Gold, R. M., \& Wright, R. F. (2020). The Political Patterns of Bail Reform. Wake Forest Law Review. 55, 743-756.

Green, B. (2020). The false promise of risk assessments: Epistemic reform and the limits of fairness. Proceedings of the 2020 Conference on Fairness, Accountability, and Transparency, 594-606. https://doi.org/10.1145/3351095.3372869

Gilmore, R. W. (2007). Golden Gulag: Prisons, Surplus, Crisis, and Opposition in Globalizing California. University of California Press.

Gupta, A., Hansman, C., \& Frenchman, E. (2016). The Heavy Costs of High Bail: Evidence from Judge Randomization. The Journal of Legal Studies, 45(2), 471-505. https://doi.org/10.1086/688907

Hannah-Moffat, K and K. Struthers Montford (2019) Unpacking Sentencing Algorithms Risk, Racial Accountability and Data Harms in Predictive Sentencing Normative and Empirical Perspectives. Edited by Jan W de Keijser, Julian V Roberts \& Jesper Ryberg. Hart Publishing

Holder, E. (2014, August 1). Attorney General Eric Holder Speaks at the National Association of Criminal Defense Lawyers 57th Annual Meeting and 13th State Criminal Justice Network Conference. United States Department of Justice. https://www.justice.gov/opa/speech/attorney-general-eric-holder-speaks-nationalassociation-criminal-defense-lawyers-57th

Hunter, L. (March 13, 2020). What You Need To Know About Ending Cash Bail. Center for American Progress. https://www.americanprogress.org/issues/criminaljustice/reports/2020/03/16/481543/ending-cash-bail/

Initiative, P. P. (November 17, 2020). Releasing people pretrial doesn't harm public safety. https://www.prisonpolicy.org/blog/2020/11/17/pretrial-releases/

Jessop, B. (2014). From micro-powers to governmentality: Foucault's work on statehood, state formation, statecraft and state power. In Michel Foucault. Routledge.

Kilgore, J. (2013). Progress or More of the Same? Electronic Monitoring and Parole in the Age of Mass Incarceration. Critical Criminology, 21(1), 123-139. https://doi.org/10.1007/s10612-012-9165-0

Koepke, J. L., \& Robinson, D. G. (2018). Danger Ahead: Risk Assessment and the Future of Bail Reform. Washington Law Review, 93, 1725. http://dx.doi.org/10.2139/ssrn.3041622

Mansoor, H. (2020). Guilty Until Proven Guilty: Effective Bail Reform as a Human Rights Imperative. DePaul Law Review. http://dx.doi.org/10.2139/ssrn.3566273

Mayson, S. G. (2017). Dangerous Defendants. Yale Law Journal, 127, 490.

McKay, C. (2020). Predicting risk in criminal procedure: Actuarial tools, algorithms, AI and judicial decision-making. Current Issues in Criminal Justice, 32(1), 22-39. https://doi.org/10.1080/10345329.2019.1658694

Petersen, N., \& Omori, M. (2020). Is the Process the Only Punishment?: Racial-Ethnic Disparities in Lower-Level Courts. Law \& Policy, 42(1), 56-77. https://doi.org/10.1111/lapo.12140

Pratt, J. (1995). Dangerousness, risk and technologies of power. Australian \& New Zealand Journal of Criminology, 28(1), 3-31. https://doi.org/10.1177/000486589502800102

PJI Team. (2020). Updated Position on Pretrial Risk Assessment Tools. https://www.pretrial.org/wp-content/uploads/Risk-Statement-PJI-2020.pdf

Pretrial Risk Assessment Can Produce Race-Neutral Results. (2017). Pretrial Justice Initiative. 
https://www.ncsc.org/_data/assets/pdf_file/0012/1650/pretrial-risk-assessment-canproduce-race-neutral-results-pji-2017.ashx.pdf

Rengifo, A. F., Flores, S. G., \& Jackson, A. N. (2021). From Bright Plots to Blind Spots: Mapping Departures in Case Review Post-Bail Reform in Two New Jersey Courts. Criminal Justice and Behavior, 48(1), 96-115. https://doi.org/10.1177/0093854820960504

Rickert, C. (2018, July 3). Life on a bracelet: GPS monitoring an 'invisible fence,' chance to 'reevaluate' | Local Government | madison.com. Wisconsin State Journal. https://madison.com/wsj/news/local/govt-and-politics/life-on-a-bracelet-gps-monitoringan-invisible-fence-chance/article_35b9e832-fce8-5409-b7a5a47a0111ae41.html?utm_medium=social\&utm_source=email\&utm_campaign=usershare

Rockett, D. (2019). Poor people often can't afford to pay bail. Chicago Tribune March, 7, 2019. https://www.chicagotribune.com/lifestyles/ct-life-appolition-making-bail-20190124story.html

Rose, N. (2001). The Politics of Life Itself. Theory, Culture \& Society, 18(6), 1-30. https://doi.org/10.1177/02632760122052020

Sawyer, W. (2019, October 9). How race impacts who is detained pretrial. Prison Policy Initiative. https://www.prisonpolicy.org/blog/2019/10/09/pretrial_race/

Schuppe J. (January 7, 2020). Unintended consequences: Days after ending cash bail, New York has second thoughts. NBC News. https://www.nbcnews.com/news/crime-courts/fair-ordangerous-days-after-ending-cash-bail-new-york-n1111346

Starger, C., \& Bullock, M. (2017). Legitimacy, Authority, and the Right to Affordable Bail. William \& Mary Bill of Rights Journal, 26, 589.

The Bail Project: After Cash Bail. (2020). The Bail Project. Retrieved June 22, 2021, from https://bailproject.org/after-cash-bail/

Tolan, C. (2017). Making Freedom Free. Slate. https://slate.com/news-and-politics/2017/03/poordefendants-get-locked-up-because-they-cant-afford-cash-bail-heres-an-easy-fix.html

Werth, R. (2019). Theorizing the performative effects of penal risk technologies:(Re) producing the subject who must be dangerous. Social \& Legal Studies, 28(3), 327-348.

Werth, R. (2019). Risk and punishment: The recent history and uncertain future of actuarial, algorithmic, and 'evidence-based' penal techniques. Sociology Compass, 13(2), e12659. https://doi.org/10.1111/soc4.12659

What's Happening in Pretrial Justice Q4 2020. (2021). Pretrial Justice Initiative. https://university.pretrial.org/viewdocument/where-pretrial-improvements-are-hap-2

Whitehead, S. N. (2015). The specter of racism: Exploring White racial anxieties in the context of policing. Contemporary Justice Review, 18(2), 121-138. https://doi.org/10.1080/10282580.2015.1025622

Wright, W. (2016). Finding a Home in the Stop-and-Frisk Regime. Social Justice, $43(3$ (145)), 25-45. 